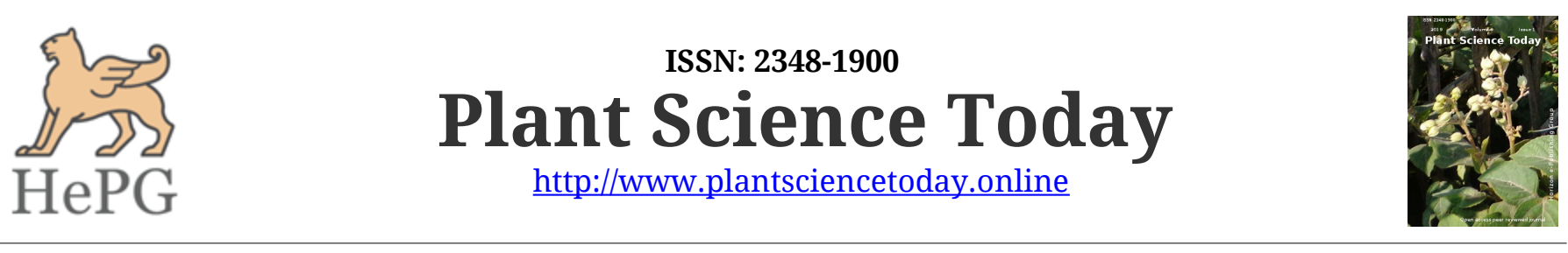

OPEN ACCESS

Research Communication

\title{
Salvia reflexa (Lamiaceae): a new record for Pakistan
}

\author{
Wahid Hussain ${ }^{1}$, Lal Badshah ${ }^{2}$, Sayed Afzal Shah ${ }^{3}$, Farrukh Hussain ${ }^{4}$, Asghar Ali ${ }^{5}$, Shamim-ul-Sibtain \\ Shah $^{6}$ and Amir Sultan ${ }^{7}$
}

${ }^{1}$ Department of Botany, Government Post Graduate College, Parachinar, Pakistan

${ }^{2}$ Phytoecology Lab., Department of Botany, University of Peshawar, 25000, Pakistan

${ }^{3}$ Department of Plant Sciences, Quaid-i-Azam University, Islamabad, Pakistan

${ }^{4}$ Institute of Biological Science, Sarhad University of Science and Technology, Peshawar, Pakistan

${ }^{5}$ Department of Botany, Government AKL Post Graduate College, Matta, Swat, Pakistan

${ }^{6}$ Farm Operations \& Services, National Agricultural Research Centre, Park Road, Islamabad, Pakistan

${ }^{7}$ National Herbarium (Stewart Collection), National Agricultural Research Centre, Park Road, Islamabad, Pakistan

\section{Article history}

Received: 30 September 2018 Accepted: 29 December 2018

Published: 12 January 2019

\section{Editor}

Dr Nishikant Wase

University of Nebraska-Lincoln USA

\section{Publisher}

Horizon e-Publishing Group

\author{
*Correspondence \\ Wahid Hussain \\ $\bigotimes_{\text {wahidhussainwahid@gmail.com }}$
}

\begin{abstract}
Salvia reflexa Hornem., a member of the New World subgenus Calosphace, ranges from North America to southern South America, Australia, New Zealand, South Africa and Afghanistan in Asia, and still continues to expand its range. Here we report further range expansion for $S$. reflexa into the tribal areas of Pakistan and hypothesize that it has been introduced from Afghanistan. This represents a new record for the flora of Pakistan.
\end{abstract}

\author{
Keywords \\ Salvia reflexa Hornem.; Kurram; Koh-e-Safaid; New Record; Pakistan
}

Citation

Hussain W, Badshah L, Shah SA, Hussain F, Ali A, Shah SS, Sultan A. Salvia reflexa (Lamiaceae): a new record for Pakistan. Plant Science Today 2019;6(1):17-21. https://doi.org/10.14719/pst.2019.6.1.431

\begin{abstract}
Copyright: (C) Hussain et al. (2019). This is an open-access article distributed under the terms of the Creative Commons Attribution License, which permits unrestricted use, distribution, and reproduction in any medium, provided the original author and source are credited (https://creativecommons.org/licenses/by/4.0/).
\end{abstract}

Indexing: Plant Science Today is covered by Scopus, CAS, AGRIS, CABI, Google Scholar, etc. Full list at http://www.plantsciencetoday.online

\section{Introduction}

Salvia reflexa Hornem., an annual labiate, belongs to the New World subgenus Calosphace that ranges from the Great Plains of the United States to southern South America. The group has originated in Western Mexico and has four centres of diversity viz., Mexico and Central America, Andean Cordillera, eastern South America and the Caribbean Antilles (1). Salvia reflexa is important weed in the United States $(2,3)$. However, reports have shown that it has expanded its range to South America, Australia, New Zealand (4) as well as Afghanistan in Asia (5) and Southern Africa (6). It was introduced to Australia, and probably to other regions of the world, from North America (7).

Although several species of Salvia are used in folk medicine, S. reflexa has been shown to be poisonous to livestock in Australia and Argentina $(8,9)$ but is only responsible for losses when hungry animals are introduced to populations of the weed (10). It is reported from Venezuela to cause nitrite intoxication, intense inflammation of gastrointestinal tract and death in cows, horses and sheep (11). An exceptional case occurred in Queensland (Australia) in 1932 when 324 bullocks died due to consumption of $S$. reflexa. It contains up 
to 5 percent of potassium nitrate on a dry matter basis. The water extract of two pounds of the plant can cause death due to methaemglobinaemia (8). Aerial parts of this plant contains diterpenoids Salviarin and 6 $\beta$-hydroxysalviarin, the neoclerodane and the 5,6-secoclerodane, whereas the roots contain oleanolic acid and $\beta$-sitosterol (12). Salvia reflexa has been shown to contain rosmarinic acid as the dominant naturally occurring compound and has high antioxidant activity (13).

Salvia reflexa is adventive and grows as a weed in row crops and ruderal vegetation along roads. Several factors including seed dormancy (14), the ability to emerge within a broad temperature range (15), and low water potential (16) have enabled $S$. reflexa to be a troublesome weed in several cultivated crops like safflower, sorghum, sugar beet and wheat. Its growth begins in spring and continues throughout the frost-free period, with the possibility of several germinations during summer if rainfall is sufficient. In Australia it is usually found on more fertile soils, particularly the red and black clays of the north, north-west and parts of the western areas of New South Wales (17). It is a rapid colonizer and has the ability to overrun valuable country and to render it unproductive (10). Studies have shown that it is not a strong competitor of wheat and sugar beet. However, appropriate control measures should be undertaken to minimize yield loss from interference $(10,18)$.

The present study highlights further range expansion of S. reflexa in Asia and represents a new record for the flora of Pakistan.

\section{Materials and Methods}

The plant was initially collected by the first author during a field visit in 2015 from the Koh-i-Sufaid range in Kurram district (formerly an agency of Federally Administered Tribal Areas) of Khyber Pakhtunkhwa province. In the subsequent two years the adjacent areas were thoroughly searched to locate more occurrences. The identity of collected specimens was confirmed by Dr. Jesús Gonzales and Dr. Bryan Drew. Herbarium specimens were deposited in PUP and RAW. Moreover, the seeds were germinated under normal field conditions at Islamabad in order to record further observations relating to morphology of the plant.

\section{Results and Discussion}

Key to Salvia species in Kurram (modified from Flora of Pakistan)

1. + Leaves densely white pannose on the abaxial surface S. moorcroftiana
Leaves not white pannose on the abaxial surface 2

2. + Leaf bases hastate-sagittate, corolla pale yellow S. nubicola

- Leaf bases not hastate-sagittae, corolla pale lilac, violet-blue, pale lavender or white 3

3. + Calyx with numerous capitate glandular hairs and few eglandular hairs S. aegyptiaca

4. - Calyx lacking capitate glandular hairs, but with eglandular hairs along veins and with sessile glands between veins S. reflexa

Salvia reflexa Hornem, Enumeratio Plantarum Horti Botanici Hafniensis 34. 1807.

Description: Annual herb c. $50 \mathrm{~cm}$ tall. Tap root fibrous. Stem green, 4-angled, covered with short rigid retrorse hairs. Leaves opposite, decussate, 3$6.5 \mathrm{~cm} \times 8-14 \mathrm{~mm}$, glabrous on the adaxial surface, sparsely pubescent on the abaxial surface, petiolate, petiole 1-4 $\mathrm{cm}$ long, petiole pubescent, lamina lanceolate, obtuse, cuneate, crenate, nerves in 5-6 opposite or alternate pairs. Flowers bracteate, borne in terminal verticillasters. Pedicel c. $2 \mathrm{~mm}$. Bracts $0.4-0.5 \mathrm{~cm} \times 1 \mathrm{~mm}$, acuminate, calyx, green, tubular, 4-8 $\mathrm{mm}$ long, hairy along nerves, gland dotted between nerves, throat sparsely hairy, persistent, pale brown at maturity, upper lip acute, 5 nerved, lower lip bifid, 7 nerved. Corolla pale lilac to white, $0.8-1 \times 0.6 \mathrm{~cm}$, internally pubescent, upper lip smaller, lower lip laterally lobed, apex emarginate. Anthers c. $1 \mathrm{~mm}$ long, filament about $2 \mathrm{~mm}$. Carpel c. $7 \mathrm{~mm}$, ovary c. $1 \mathrm{~mm}$. Nutlets, oblong, flat, yellowish, c. $1.5 \mathrm{~mm}$ long, surface reticulate (Fig. 1).

Specimens examined: Wahid Hussain, from different localities of Parachinar: Shalozan; Luqman Khail; Pewar; Nastikot; Kharlachi; Tari Mangal, and Parachinar, $6^{\text {th }}$ July 2016 (PUP).

\section{Dominant and associated species}

Dominant and associated species include Hertia intermedia Kuntze, Seriphidium kurramense (Qazilb.) Y.R. Ling, Salvia nubicola Wall. ex Sweet, Euphorbia prostrata Aiton, Tagetes minuta L. and Saccharum rufipilum Steud.

\section{Flowering Period}

Field observations suggest that flowering of this species occurs from May-October. It has been observed that after flowering seeds are formed within 15 to 20 days and plants complete their life cycle from May to October.

\section{Medicinal uses}

In Parachinar (Kurram Valley) local healers use $S$. reflexa to treat diabetes. 


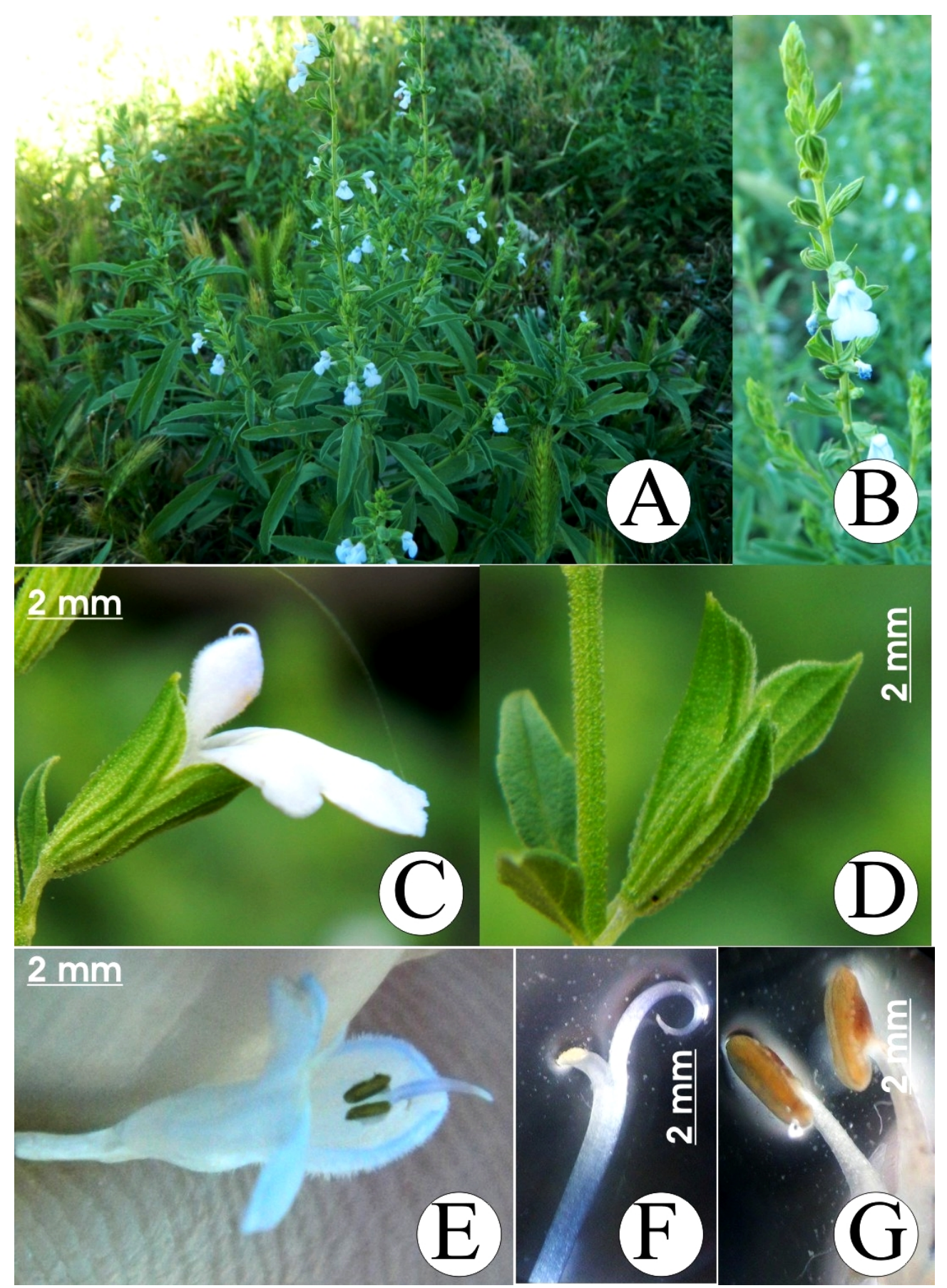

Fig. 1. Salvia reflexa A. Habit; B. Inflorescence; C. Flower; D. Calyx; E. Corolla tube dissected; F. Style; G. Androecium.

Table 1. List of collection localities of Salvia reflexa in Kurram Agency, Pakistan

\begin{tabular}{ll}
\hline Location & Habitat \\
\hline Shalozan & Flooded ravines \\
\hline Luqman Khail & Gullies \\
\hline Pewar & Open sandy soils \\
\hline Nastikot & Stream banks \\
\hline Kharlachi & Barren fields \\
\hline Tari Mangal & Road sides \\
\hline Parachinar & Road sides \\
\hline
\end{tabular}

\section{Distribution and Habitat}

Previously, this species has been reported from North America, South America, Canada, Russia, China, Australia and New Zealand. It was first recorded in Australia near Pittsworth, Queensland at the beginning of this century and it is thought to be introduced during 1902 drought as contaminant in fodder from United States. We recorded Salvia reflexa from different localities of Kurram Agency (Table 1, Fig. 2). It is an invasive weed found in flooded ravines, gullies, and cultivated wheat fields, along road sides, sandy loams and fertile clay soils of Koh-e-Sufaid range in the upper Kurram Agency. It was collected from the sub- 


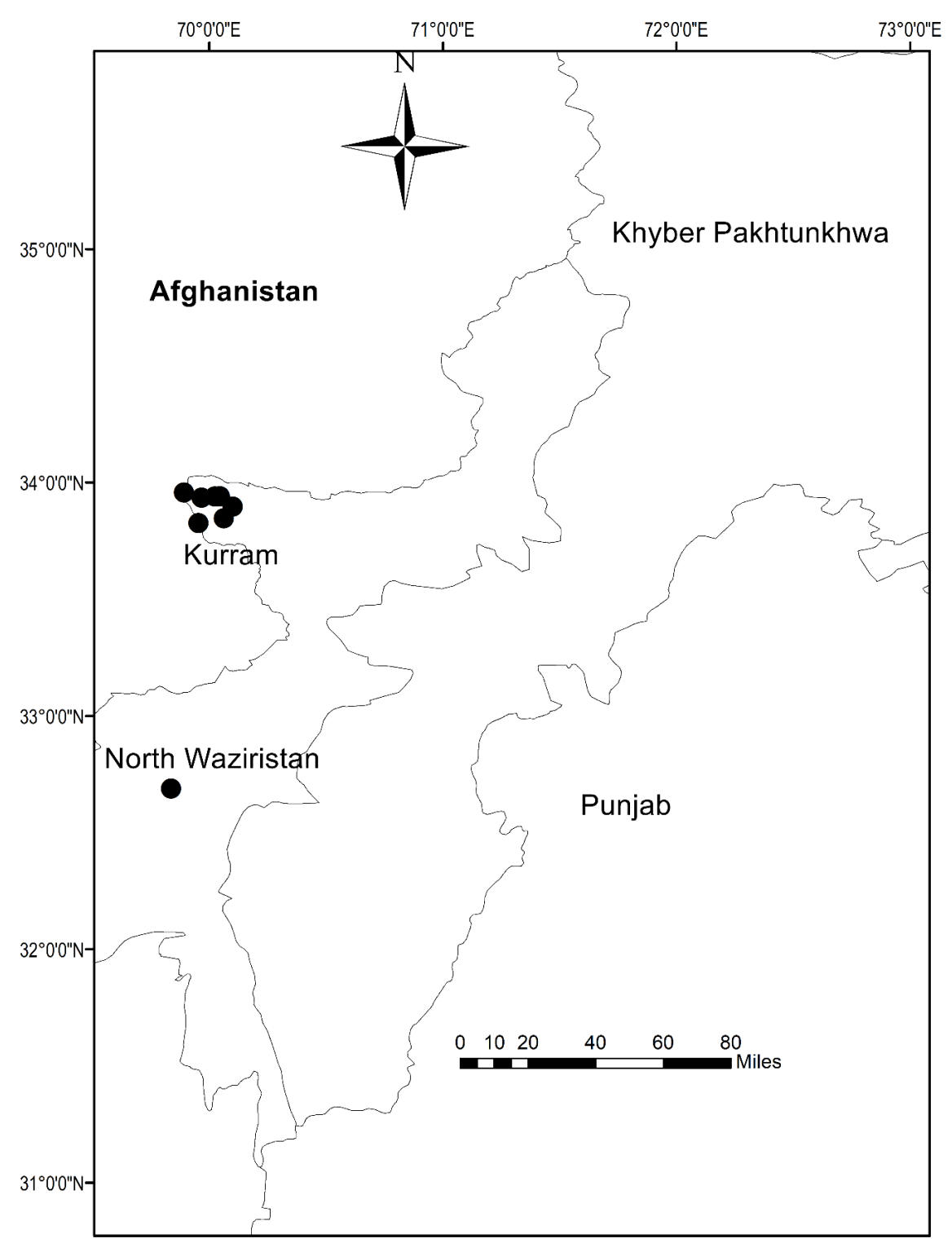

Fig. 2. Map showing collection localities of Salvia reflexa

tropical zone between 1328-1965 m, on open sandy soils in plains of Upper Kurram Valley, Khyber Pakhtunkhwa, Pakistan. In another field visit some plants were also witnessed in Razmak, North Waziristan, Khyber Pakhtunkhwa. This species seems to have secured a pretty broader range in tribal areas of Pakistan. Both Kurram and North Waziristan districts are situated along border of neighbouring Afghanistan. As we recorded a population of $S$. reflexa along the border between Pakistan and Afghanistan in Parachinar, this plant has potentially been introduced to Pakistan from Afghanistan in the past decades. The earlier report of $S$. reflexa from Afghanistan (5) and the absence of $S$. reflexa in the published flora of Pakistan (19) and annotated catalogue of the vascular plants of West Pakistan and Kashmir (20) support our view.

\section{Potential and success of $S$. reflexa as a weed}

Since the plant is a weedy species, extant of its distribution in Pakistan needs to be determined and suitable eradication measures employed to avoid further spread in our areas. Some germination of $S$. reflexa could occur from 4 to $39^{\circ} \mathrm{C}$, with good germination between 12 and $32^{\circ} \mathrm{C}$ and the best germination occurs at $28-32^{\circ} \mathrm{C}$. Germination occurs at a higher osmotic potential than in most species previously reported (14). This wide tolerance of environmental factors affecting germination should enable $S$. reflexa to be competitive over a wide range of field conditions. It has a prolonged flowering period resulting in prolific seed production and since it reproduces only from seed this, in large measure, is responsible for its weed status. It is primarily a species of temporary habitats, where it is always exposed to the risk of total elimination, but for a reservoir of seeds in the soil. Germination and subsequent emergence of $S$. reflexa seedlings is an irregular process with several germinations occurring during summer if rainfall is sufficient (17). Moreover, dry winters conditions are conducive to its spread, which leave paddocks 
with little ground cover in early spring, followed by wet summers (10). The temperature and soil conditions of Balochistan and the bordering areas of Khyber Pakhtunkhwa with Afghanistan are highly suitable for the existence of $S$. reflexa. As part of this work we performed experiments with germination of $S$. reflexa seeds at Botanical Conservatory, National Agriculture Research Center; Islamabad in the summers 2018 under normal field conditions. The germination of seeds and subsequently the growth, flowering and production of seeds were highly successful. The experiment suggests that $S$. reflexa has the potential to establish its populations in most important agricultural lands of Pakistan i.e. Punjab. Therefore, this new introduction needs to be properly managed before its expansion in to the agricultural lands.

\section{Ethics approval and consent to participate}

Letters of permission were obtained from Peshawar University and local administration office prior to the data collections. Verbal consent was also obtained from the local informants about the aims and objectives of the study prior to the interviews, and all the field data were collected through their consents. No further ethics approval was required.

\section{Competing interests}

The authors declared that they have no competing interest.

\section{Author's contribution}

WH collected the field data and wrote initial draft of the manuscript, LB supervised the project, SAS, FH, AA, SS and AS helped in data analysis and revision of the manuscript. All the authors approved the final manuscript after revision.

\section{Acknowledgements}

This work is part of doctoral research of the first author. We are thankful to, Dr. Jesús Gonzales and Dr. Bryan Drew for confirming the identity of plant.

\section{References}

1. Jenks AA. Walker JB, Kim SC. Phylogeny of New World Salvia subgenus Calosphace (Lamiaceae) based on cpDNA (psbA-trnH) and nrDNA (ITS) sequence data. Journal of Plant Research 2013; 126(4): 483-496. https://doi.org/10.1007/s10265-012-0543-1

2. Baskin JM, Baskin CC. Salvia reflexa new to Tennessee. Castanea 1971; 77-79.

3. Nussbaum, E.S. The effects of temperature and rainfall on emergence and growth of eight weeds. Weed Science 1985; 33(2): 165-170.
4. Holm L, Pancho JV, Herberger JP, Plucknett DL. A geographical atlas of world weeds. John Wiley and Sons; 1979.

5. Tamura, M, New species from Afghanistan collected by the Kyoto University Scientific Expedition 1955. Acta Phytotaxonomica et Geobotanica 1956; 16(5):141-142.

6. Jäger AK, Van Staden J. Salvia in southern Africa. The Genus Salvia 2000; 289.

7. Roe R, Shaw NH. Mint weed, Salvia reflexa Hornem. Present distribution and status in Australia. Bulletin of Council of Scientific Industry Research 1947; 23.

8. Williams $\mathrm{CH}$, Hines HJG. The toxic properties of Salvia reflexa. Australian Veterinary Journal 1940; 16(1): 1420. https://doi.org/10.1111/j.1751-0813.1940.tb01259.x

9. Everist SL, Poisonous plants of Australia. Sydney, etc.: Angus \& Robertson; 1974.

10. Lovett J, Lynch J. Studies of Salvia reflexa Hornem. I. Possible competitive mechanisms. Weed Research 1979; 19(6): 351-357. https://doi.org/10.1111/j.13653180.1979.tb01550.x

11. Alonso-Amelot, ME, Arellano E, Avila JL, Aubert L, Romero R, Calcagno MP, Avendafio M, Perez M, Otero LD. A Survey of Venezuelan Plants Toxic to. Poisonous Plants and Related Toxins 2004; 471.

12. Nieto M, Gallardo VO, Rossomando PC, Tonn CE. 8HydroxySalviarin and 7, 8-didehydrorhyacophiline, two new diterpenes from Salvia reflexa. Journal of natural products 1996; 59(9): 880-882. https://doi.org/10.1021/np960515x

13. Malenčić, D, Gašić O, Popović M, Boža P. Screening for antioxidant properties of Salvia reflexa Hornem. Phytotherapy Research 2000; 14(7): 546-548. https://doi.org/10.1002/10991573(200011)14:7\%3C546::AID-PTR658\%3E3.0.CO;2-K

14. Weerakoon W, Lovett J. Studies of Salvia reflexa Hornem. III. Factors controlling germination. Weed research 1986; 26(4): 269-276. https://doi.org/10.1111/j.1365-3180.1986.tb00706.x

15. Weerakoon WL. Studies on the autecology of Salvia reflexa Hornem (mintweed) with special reference to weed management. Journal of the Australian Institute of Agricultural Science 1981; 47:218.

16. Weerakoon WL, Lovett J. Studies of Salvia reflexa Hornem. IV. Effects of watering frequency, drought and nutrient supply on growth and development. $\begin{array}{llll}\text { Weed research 1986; } 26(4): & 277-282 .\end{array}$ https://doi.org/10.1111/j.1365-3180.1986.tb00707.x

17. Freebairn R, Strang J. Mintweed in perspective. Agric. Gaz. New South Wales 1974; 85: 26-28.

18. Odero DC, Mesbah AO, Miller SD, Kniss AR. Lanceleaf sage (Salvia reflexa) interference in sugarbeet. Weed $\begin{array}{lll}\text { Technology } & \text { 2010; } & \text { 24(4): }\end{array}$ https://doi.org/10.1614/WT-D-10-00015.1

19. Hedge I. Labiatae in Flora of Pakistan (University of Karachi, Karachi) 1990; 192: 310.

20. Stewart RR. An annotated catalogue of the vascular plants of West Pakistan and Kashmir. Fakhri Print. Press; 1972. 